\title{
Removal of Olive Mill Wastewater Phenolics with the Use of a Polyphenol Oxidase Homogenate from Potato Peel Waste
}

\author{
Florin Daniel Demian' ${ }^{1}$ and Dimitris P. Makris ${ }^{2}$ \\ ${ }^{1}$ Laboratory of Chemistry of Natural Products, Mediterranean Agronomic Institute of Chania (M.A.I.Ch.), \\ P.O. Box 85, 73100 Chania, Greece \\ ${ }^{2}$ School of Environment, University of the Aegean, Mitr. Ioakim Street, Lemnos, 81400 Myrina, Greece \\ Correspondence should be addressed to Dimitris P. Makris; dmakris@aegean.gr
}

Received 17 September 2013; Accepted 1 November 2013

Academic Editor: Milva Pepi

Copyright (c) 2013 F. D. Demian and D. P. Makris. This is an open access article distributed under the Creative Commons Attribution License, which permits unrestricted use, distribution, and reproduction in any medium, provided the original work is properly cited.

\begin{abstract}
Olive mill wastewater (OMW) originating from a two-phase olive oil producing plant was treated with a crude polyphenol oxidase (PPO) homogenate, prepared from potato waste peels. The treatments carried out were based on a $2^{3}$-full-factorial, central composite design (CCD) in order to identify optimal operational conditions with regard to polyethylene glycol (PEG) concentration, $\mathrm{pH}$, and treatment duration. The treatment performance was assessed by estimating the \% reduction in total polyphenol (TP) concentration. The model obtained produced a satisfactory fitting of the data $\left(R^{2}=0.96, P=0.0017\right)$. The utilisation of the predictive model enabled the theoretical calculation of the optimal set of conditions, which were $\mathrm{pH}=4, t=3.57 \mathrm{~h}$, and $[\mathrm{PEG}]=900 \mathrm{mg} \mathrm{L}^{-1}$. Under these conditions, the optimal theoretical \% removal calculated was $54 \pm 9$. Examination of the treated samples with high-performance liquid chromatography (HPLC) showed that the potato homogenate afforded changes in the polyphenolic profile. Based on the experimental evidence, oxidation pathways were proposed.
\end{abstract}

\section{Introduction}

Olive mill wastewater (OMW) is a highly polluting effluent of olive oil production and its disposal is a serious environmental peril. The main negative effect associated with its dumping is the high toxicity to plants, microorganisms, and aquatic organisms [1]. Thus, OMW is not appropriate for watering and fertilizing purposes and it is recalcitrant to biodegradation by bacteria and fungi. The toxicity of OMW is largely attributed to its exceptionally high polyphenolic burden, which may reach up to $80 \mathrm{~g} \mathrm{~L}^{-1}$. This lends OMW a $\mathrm{COD} / \mathrm{BOD}_{5}$ ratio of $2.5-5$, which makes it 5-80 times stronger pollutant than domestic sewage [1].

The remediation of OMW has been a subject of several studies, dealing with catalysis-based oxygenation with various inorganic catalysts [2] and biological treatment, mainly with laccase- or peroxidase-producing fungi [3-7]. The use of enzymes in bioremediation processes has gained a wide acceptance because of the recognition that enzymes from various plant and microbial sources have several advantages over conventional physical and chemical treatments. These advantages include selective removal of particular pollutants, application to xenobiotic recalcitrant compounds, high reaction rates, operation over a wide range of $\mathrm{pH}$ and salinity, reduction in sludge volume, and simplicity of controlling the process $[8,9]$.

Among the enzymatic processes for waste treatment, peroxidase- and polyphenol oxidase-catalysed treatments of phenols are probably the most comprehensively studied [10]. Plant food wastes and byproducts, including trimmings and peels, might contain a range of enzymes capable of transforming bioorganic molecules, and thus they may have potential uses in bioremediation processes [11]. PPO from potato, in particular, has been shown to effectively polymerise lignin fragments in artificial wastewater, in combination with peroxidase [12], detoxify bisphenol A [13], decolourise dying effluents $[14,15]$, degrade pentachlorophenol [16], and remove phenol [17] and other halogenated phenols [18] from aqueous effluents. 
To the best of our knowledge, potato PPO has never been investigated for its potential to remove OMW phenolics. On such a conceptual basis, this study was undertaken to examine the prospect of using crude potato peel PPO to remove OMW phenolics, by the application of a $2^{3}$-fullfactorial design and response surface methodology, including $\mathrm{pH}$, treatment time, and polyethylene glycol (PEG) as critical factors.

\section{Materials and Methods}

2.1. Reagents and Chemicals. Bradford reagent, trans-chlorogenic acid (CGA), trichloroacetic acid (TCA), and 4-aminoantipyrine (4-AAP) were from Sigma Chemical Co. (St. Louis, MO, USA). N,N-Dimethylformamide (DMF) and potassium ferricyanide were from Merck (Darmstadt, Germany).

2.2. Olive Mill Wastewater (OMW). The OMW was obtained from a two-phase processing plant, located within the prefecture of Chania (Crete, Greece). The plant processes organically cultivated olives for the production of extravirgin olive oil. The OMW was collected immediately after disposal to avoid any changes in the polyphenolic composition. Upon reception, the waste was stored at $4^{\circ} \mathrm{C}$ in the dark until used for no longer than a week.

2.3. Preparation of the Potato Peel Homogenate. Brown-skin potatoes (Solanum tuberosum L.) were purchased from a grocery (Chania, Crete). The tubers were transferred to the laboratory and manually peeled, and the peels were immediately frozen with liquid nitrogen. The frozen tissue was ground with a pestle and a mortar and mixed with charcoal to remove phenolics. Typically, $1 \mathrm{~g}$ of charcoal was used for approximately $25 \mathrm{~g}$ of ground tissue. The charcoaltreated tissue was then mixed with $150 \mathrm{~mL}$ of phosphate buffer (50 mM, pH 6.6) and homogenised in a domestic blender to form slurry. The homogenate was centrifuged at $4000 \mathrm{~g}$ for $15 \mathrm{~min}$ and filtered through paper filter. The clear filtrate was used as crude enzyme source.

2.4. Polyphenol Oxidase Activity. The assay mixture contained $0.25 \mathrm{~mL}$ 4-AAP ( $10 \mathrm{mM}$ in water), $0.1 \mathrm{~mL}$ substrate (100 mM CGA in DMF), $0.6 \mathrm{~mL}$ of phosphate buffer $(50 \mathrm{mM}$, $\mathrm{pH}$ 6.6), and $0.1 \mathrm{~mL}$ enzyme extract. The formation of chromogen (quinoneimine dye) adduct of 4-AAP/CGA was monitored by recording the absorbance at $510 \mathrm{~nm}\left(A_{510}\right)$ for over $3 \mathrm{~min}$ against suitable blank. One enzyme unit (U) was defined as $\mu$ moles of quinoneimine dye formed per min. For all determinations, $\varepsilon=12,000$ was used for the quinoneimine dye [19]. Control reactions by using heat-inactivated homogenate were also carried out. For all determinations, a computer-controlled HP 8452A diodearray spectrophotometer was used. Protein content was determined according to Bradford 1976 [20], using bovine serum albumin as the standard.

2.5. Enzymatic Treatment. The waste was homogenised by vigorous shaking, then filtered through filter paper, and
TABLE 1: Experimental values and coded levels of the independent variables used for the $2^{3}$-full-factorial design.

\begin{tabular}{lcccc}
\hline \multirow{2}{*}{ Independent variables } & \multirow{2}{*}{ Code units } & \multicolumn{3}{c}{ Coded variable level } \\
& & -1 & 0 & 1 \\
\hline PEG] $\left(\mathrm{mg} \mathrm{L}^{-1}\right)$ & $X_{1}$ & 100 & 500 & 900 \\
$\mathrm{pH}$ & $X_{2}$ & 4 & 6 & 8 \\
Time (h) & $X_{3}$ & 1 & 3 & 5 \\
\hline
\end{tabular}

diluted 1:20 with tap water. The OMW was adjusted at various pH levels (Table 1), using either $0.1 \mathrm{~N} \mathrm{HCl}$ or $0.1 \mathrm{~N} \mathrm{NaOH}$. The medium (final volume, $20 \mathrm{~mL}$ ) was composed of $19 \mathrm{~mL}$ OMW, $0.5 \mathrm{~mL}$ crude PPO extract (final total protein concentration, $1.55 \mu \mathrm{g} \mathrm{mL}^{-1}, 1.42 \mathrm{U}$ ), and $0.5 \mathrm{~mL}$ PEG solution. The final mixture was placed in a $30 \mathrm{~mL}$ screw-cap, glass reactor, bearing a teflon-coated magnetic stirrer, and sparged with air for $5 \mathrm{~min}$ prior to treatments to ascertain the presence of sufficient amount of oxygen. Treatments were carried out under stirring with a magnetic stirrer, operating at $400 \mathrm{rpm}$. Control treatments with heat-inactivated homogenate were also carried out.

2.6. Total Polyphenol Determination. A sample $(1 \mathrm{~mL})$ was withdrawn from the reaction medium and placed in a $1.5 \mathrm{~mL}$ Eppendorf tube. The sample was mixed with $0.1 \mathrm{~mL}$ TCA, vortexed, and then centrifuged in a table centrifugator at $10,000 \mathrm{rpm}$. An aliquot of $0.5 \mathrm{~mL}$ of appropriately diluted OMW was mixed with $0.3 \mathrm{~mL}$ deionised water, $0.1 \mathrm{~mL} 4$-AAP (20 $\mathrm{mM}$ in $0.25 \mathrm{M} \mathrm{NaHCO}$ ), and $0.1 \mathrm{~mL}$ potassium ferricyanide ( $85 \mathrm{mM}$ in $0.25 \mathrm{M} \mathrm{NaHCO}_{3}$ ). Absorbance readings were carried out at $510 \mathrm{~nm}$ against suitable blank [21]. Results were expressed as caffeic acid equivalents (CAE), using a calibration curve of $A_{510}$ against caffeic acid concentration (12.5-200 $\left.\mathrm{mg} \mathrm{L}^{-1}\right)$.

2.7. Experimental Design and Statistical Analyses. A $2^{3}$ full-factorial experimental design was used to identify the relationship existing between the response function and process variables as well as to determine those conditions that optimised the PPO-catalysed oxidation process. The response function considered was the $\%$ removal of TP from the reaction medium. The three independent variables or factors considered were PEG ( $X_{1}$, varying between 100 and $\left.900 \mathrm{mg} \mathrm{L}^{-1}\right), \mathrm{pH}\left(X_{2}\right.$, varying between 4 and 8$)$, and time $\left(X_{3}\right.$, varying between 1 and $5 \mathrm{~h}$ ). Each variable to be optimised was coded at three levels, $-1,0$, and 1 (Table 1). The value ranges used for PEG were based on preliminary experiments and the literature data $[21,22]$.

The three independent variables were coded according to the following equation:

$$
x_{i}=\frac{X_{i}-X_{0}}{\triangle X_{i}}, \quad x_{i}=1,2,3,
$$

where $x_{i}$ and $X_{i}$ are the dimensionless and the actual value of the independent variable $i, X_{0}$ is the actual value of the independent variable $i$ at the central point, and $\Delta X_{i}$ 
TABLE 2: Measured and predicted \% TP removal values determined for individual design points.

\begin{tabular}{lccccc}
\hline \multirow{2}{*}{ Design point } & \multicolumn{6}{c}{ Independent variables } & \multicolumn{2}{c}{ Response (\% TP removal) } \\
& $X_{1}$ & $X_{2}$ & $X_{3}$ & Observed & Predicted \\
\hline 1 & -1 & -1 & -1 & 42.6 & 42.2 \\
2 & -1 & -1 & 1 & 42.1 & 41.5 \\
3 & -1 & 1 & -1 & 35.7 & 34.3 \\
4 & -1 & 1 & 1 & 34.0 & 32.9 \\
5 & 1 & -1 & -1 & 40.0 & 39.7 \\
6 & 1 & -1 & 1 & 25.5 & 25.5 \\
7 & 1 & 1 & -1 & 48.5 & 47.7 \\
8 & 1 & 1 & 1 & 34.0 & 32.9 \\
9 & -1 & 0 & 0 & 0 & 3.5 \\
10 & 1 & 0 & 0 & 0 & 2.2 \\
11 & 0 & -1 & 0 & 23.0 & 24.3 \\
12 & 0 & 1 & 0 & 19.6 & 24.0 \\
13 & 0 & 0 & -1 & 40.4 & 43.3 \\
14 & 0 & 0 & 1 & 32.8 & 35.6 \\
15 & 0 & 0 & 0 & 20.0 & 14.7 \\
16 & 0 & 0 & 0 & 20.9 & 14.7 \\
\hline
\end{tabular}

is the step change of $X_{i}$ corresponding to a unit variation of the dimensionless value. Response at each design point was recorded (Table 2). Data from the central composite experimental design were subjected to regression analysis using least square regression methodology to obtain the parameters of the mathematical models.

Student's $t$-test permitted the checking of the statistical significance of the regression coefficients deriving from the model. Analysis of variance (ANOVA) was applied to evaluate the statistical significance of the model. Response surface plots were obtained using the fitted model, by keeping the independent variables simultaneous. All determinations were carried out at least in triplicate and values were averaged and given along the standard deviation ( \pm S.D.). For all statistics, Microsoft Excel 2000, SigmaPlot 11, and JMP 8 were used.

2.8. HPLC Analysis. The equipment utilized was an HP 1090 Series II Liquid Chromatograph, coupled with an HP 1090 diode-array detector, and controlled by Agilent ChemStation software. The column was a Phenomenex Synergi Hydro $\mathrm{RP} 18,4 \mu \mathrm{m}, 250 \times 4.6 \mathrm{~mm}$, protected by a guard volume packed with the same material. Both columns were maintained at $40^{\circ} \mathrm{C}$. Eluent (A) and eluent (B) were $0.05 \%$ aqueous trifluoroacetic acid (TFA) and acetonitrile $(\mathrm{MeCN})$ containing $0.05 \%$ TFA, respectively. The flow rate was $1 \mathrm{~mL} \mathrm{~min}^{-1}$, and the elution programme used was as follows: $5 \mathrm{~min}, 5 \%$ B; $65 \mathrm{~min}, 50 \% \mathrm{~B}$. Monitoring of the eluate was performed at $275 \mathrm{~nm}$.

\section{Results and Discussion}

3.1. Factorial Design Optimisation. Values of the independent process variables $\left(X_{1}, X_{2}\right.$, and $\left.X_{3}\right)$ are considered, and measured and predicted values for the response ( $\% \mathrm{TP}$

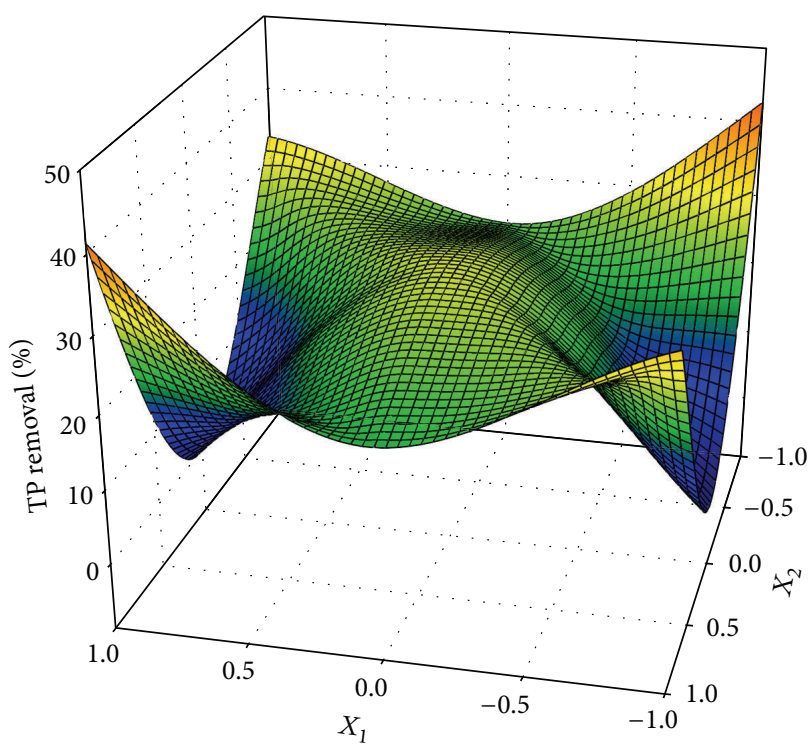

FIGURE 1: Response-surface plot illustrating the effect on \% polyphenol removal, upon simultaneous variation of PEG concentration $\left(X_{1}\right)$ and $\mathrm{pH}\left(X_{2}\right)$.

removal) are analytically given in Table 2 . The experimental values of the response were analysed by multiple regression to fit the following second-order polynomial equation:

$$
\begin{aligned}
\text { \%TP Removal }= & 14.71-0.64 X_{1}-0.14 X_{2}-3.88 X_{3} \\
& +4.00 X_{1} X_{2}-3.35 X_{1} X_{3}-0.15 X_{2} X_{3} \\
& -11.84 X_{1}^{2}+9.46 X_{2}^{2}+24.76 X_{3}^{2} .
\end{aligned}
$$

The quality of fit was ascertained using the regression coefficients $\left(R^{2}\right)$. The experimental data obtained showed a good fit with the equations $\left(R^{2}=0.96, P=0.0017\right)$. This fact indicated a satisfactory agreement between observed and predicted responses and that the equation found can adequately predict the experimental results.

After removal of the nonsignificant factors, as revealed by the ANOVA analysis, the theoretical model could be simplified as follows:

$$
\begin{aligned}
\% \mathrm{TP} \text { Removal }= & 14.71-0.14 X_{2}-3.35 X_{1} X_{3} \\
& -11.84 X_{1}^{2}+9.46 X_{2}^{2}+24.76 X_{3}^{2} .
\end{aligned}
$$

The utilisation of the predictive model enabled the theoretical calculation of the optimal set of conditions, which were $\mathrm{pH}=4, t=3.57 \mathrm{~h}$, and $[\mathrm{PEG}]=900 \mathrm{mg} \mathrm{L}^{-1}$. Under these conditions, the optimal theoretical \% removal calculated was $53.8 \pm 9.4$. The trends revealed in each case were recorded in the form of three-dimensional plots (Figures 1, 2, and 3).

The $\mathrm{pH}$ optima reported for potato PPO with CGA, which is a physiological substrate, were 4.3 [23], 5 [24], 6.5 [25], and 6.6 [26]. These discrepancies might be rather attributed to various isoforms of the enzyme that exist in potato [27]. The theoretically optimal $\mathrm{pH} 4$ calculated lies at the lower extreme of these values. However, enzyme activity is not the 


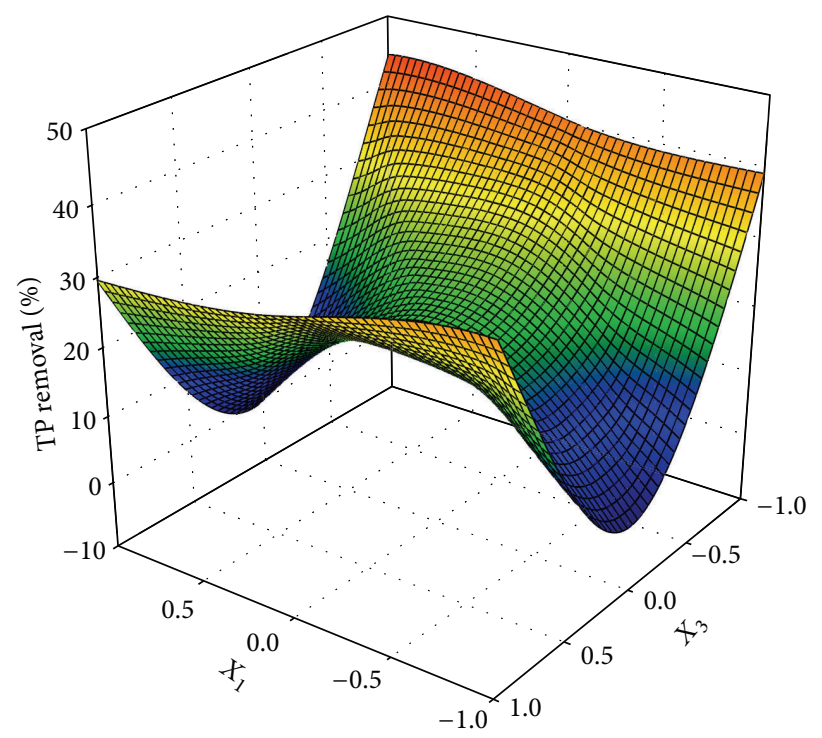

Figure 2: Response-surface plot illustrating the effect on \% polyphenol removal, upon simultaneous variation of PEG concentration $\left(X_{1}\right)$ and time $\left(X_{3}\right)$.

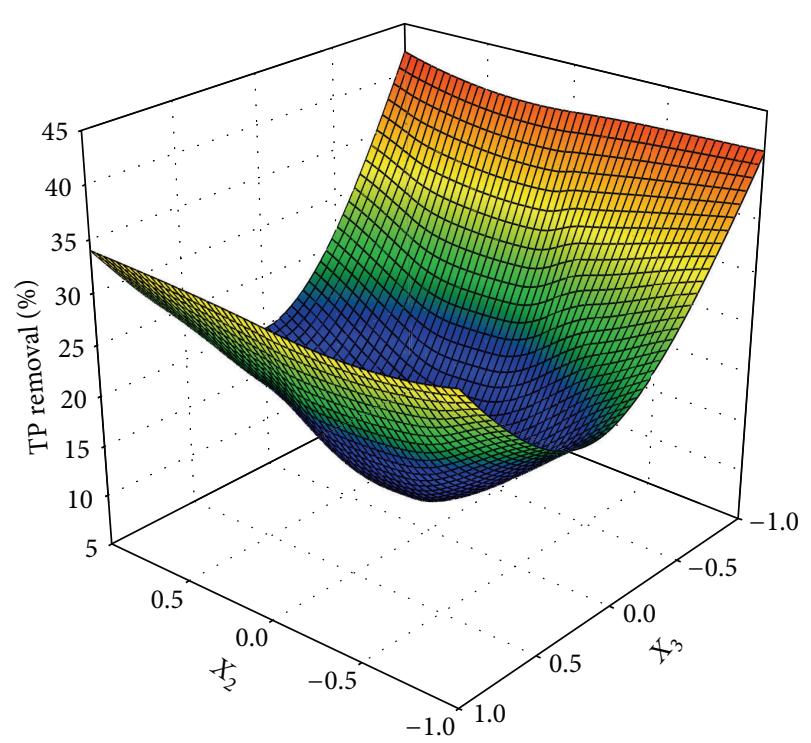

Figure 3: Response-surface plot illustrating the effect on \% polyphenol removal, upon simultaneous variation of $\mathrm{pH}\left(X_{2}\right)$ and time $\left(X_{3}\right)$.

only crucial parameter that could affect polyphenol removal. An important factor implicated could be how easily oxidised phenolics polymerise and precipitate.

In fact, previous studies demonstrated that a decrease in $\mathrm{pH}$ resulted in decreased solubility of phenol oxidation products, generated through horseradish peroxidase- (POD-) mediated oxidation [28]. Further, a decrease in $\mathrm{pH}$ was shown to enhance aggregation of chlorophenol oligomers, thus facilitating their subsequent precipitation, upon treatment with horseradish POD [29]. Therefore, it could be hypothesised that disappearance of polyphenol oxidation products, presumably through precipitation, might be promoted at $\mathrm{pH} 4$,

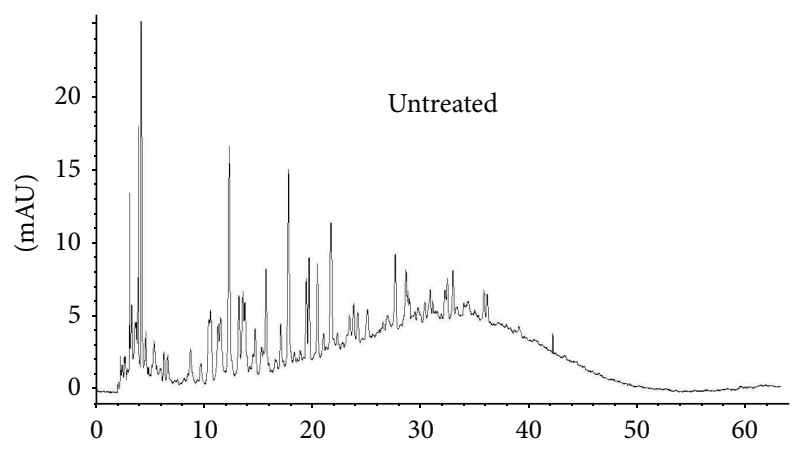

(a)

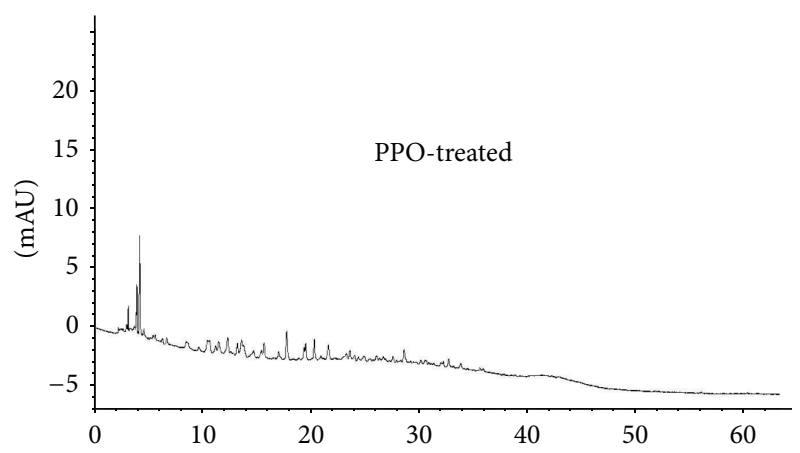

(b)

FIGURE 4: HPLC traces of original (untreated) and PPO-treated OMW. Monitoring of the eluent was performed at $275 \mathrm{~nm}$.

hence, the higher \% removal observed. Further to that, the \% removal observed should be considered as the integration of $\%$ removal of the various phenolics that may occur in OMW, since not all substances are equally removed. Immobilized laccase-catalyzed treatment of OMW indicated that removal of individual phenolics may vary from 8.8 to $99 \%$ [30].

3.2. Putative Pathways and Products. The HPLC analysis of the sample, exhibiting the highest \% polyphenol removal (no. 7, Table 2), revealed that the PPO treatment brought about significant alterations in the trace of the treated waste (Figure 4). In particular, it was observed that the major substances detected at $275 \mathrm{~nm}$ practically disappeared, but it was also noticed that there was no major qualitative change in the profile, an indication that removal of phenolics was probably achieved through the formation of insoluble polymers and that there was no formation of soluble oxidation products at least at a detectable level.

The principal phenolics detected in various OMW have been reported to be hydroxytyrosol, tyrosol, and caffeic acid [31-33], hydroxytyrosol, tyrosol, and protocatechuic acid [34], verbascoside and its derivatives [35], and several other substances; most of them are possessing an $o$-diphenol feature $[36,37]$. PPO-catalysed oxidation of $o$-diphenols proceeds through a four-electron transfer mechanism and subsequent quinone formation [38]. Quinones, in turn, can spontaneously polymerise to yield insoluble polymers [39]. Although the activity of potato PPO on monophenols is 
rather trivial [24, 40], monophenolase activity could be stimulated in the presence of $o$-diphenols [41]. In addition, monophenols could either react with the $o$-quinones formed [42] or oxidised through coupling reactions [43]. In any case, the outcome would be probably the generation of large, insoluble oligomers and/or polymers, which would be removed through precipitation, as demonstrated in several similar cases $[44,45]$. Hydroxytyrosol dimers were isolated following peroxidase $/ \mathrm{H}_{2} \mathrm{O}_{2}$-mediated hydroxytyrosol oxidation and their formation was attributed to quinone dimerisation [46].

It is certain that the exceptionally high concentration of OMW in phenolics would not permit a crude enzyme preparation to function to a satisfactory extent. The use of enzymes such as potato PPO cannot be regarded as a principal process that could efficiently remediate OMW but rather as an assisting, complementary means of removing toxic substances, thus contributing to an integrated treatment of OMWW and similar effluents. In this view, the exploitation of potato solid byproducts for producing PPO-active homogenates might merit a higher attention as a material with promising prospect in bioremediation.

\section{Conclusions}

The most important findings of this study can be summarised as follows.

(i) The implementation of a $2^{3}$-full-factorial design for the optimisation of TP removal from OMW, using a crude PPO preparation from potato peels showed that a predicted value of $53.8 \%$ can be achieved, the optimal conditions being $\mathrm{pH} 4,3.57 \mathrm{~h}$, and PEG concentration of $900 \mathrm{mg} \mathrm{L}^{-1}$.

(ii) The optimum $\mathrm{pH}$ value of the process, which differs from the $\mathrm{pH}$ optimum potato $\mathrm{PPO}$, might indicate that the catalytic activity of the enzyme, even low, is necessary to form precursors (quinones), which then can spontaneously polymerise and be removed by precipitation at $\mathrm{pH}$ lower than that of the enzyme optimal.

(iii) The chromatographic profile of the PPO-treated sample, as well as optical examination, revealed important decrease in the OMW polyphenols, which is presumably attributed to polymer formation and precipitation.

(iv) Further work is needed to examine factors pertaining to improve the process, including enzyme-to-waste ratio and temperature. In addition, analytical determinations should be undertaken to clarify the exact nature of the oxidation products.
Abbreviations
4-AAP: 4-aminoantipyrine
CCD: Central composite design
DMF: Dimethylformamide
HPLC: High-performance liquid chromatography
PEG: Polyethylene glycol

PPO: Polyphenol oxidase

POD: Peroxidase

OMW: Olive mill wastewater

TP: Total polyphenols.

\section{Conflict of Interests}

The authors declare that there is no conflict of interests regarding the publication of this paper.

\section{References}

[1] M. Niaounakis and C. P. Halvadakis, Processing Waste Management-Literature Review and Patent Survey, Elsevier, 2006.

[2] D. Mantzavinos and N. Kalogerakis, "Treatment of olive mill effluents: part I. Organic matter degradation by chemical and biological processes-an overview," Environment International, vol. 31, no. 2, pp. 289-295, 2005.

[3] M. Asgher, H. N. Bhatti, M. Ashraf, and R. L. Legge, "Recent developments in biodegradation of industrial pollutants by white rot fungi and their enzyme system," Biodegradation, vol. 19, no. 6, pp. 771-783, 2008.

[4] A. Ben Sassi, N. Ouazzani, G. M. Walker, S. Ibnsouda, M. El Mzibri, and A. Boussaid, "Detoxification of olive mill wastewaters by Moroccan yeast isolates," Biodegradation, vol. 19, no. 3, pp. 337-346, 2008.

[5] A. Tsioulpas, D. Dimou, D. Iconomou, and G. Aggelis, "Phenolic removal in olive oil mill wastewater by strains of Pleurotus spp. in respect to their phenol oxidase (laccase) activity," Bioresource Technology, vol. 84, no. 3, pp. 251-257, 2002.

[6] I. Sampedro, A. D’Annibale, J. A. Ocampo, S. R. Stazi, and I. García-Romera, "Bioconversion of olive-mill dry residue by Fusarium lateritium and subsequent impact on its phytotoxicity," Chemosphere, vol. 60, no. 10, pp. 1393-1400, 2005.

[7] M. Saavedra, E. Benitez, C. Cifuentes, and R. Nogales, "Enzyme activities and chemical changes in wet olive cake after treatment with Pleurotus ostreatus or Eisenia fetida," Biodegradation, vol. 17, no. 1, pp. 93-102, 2006.

[8] J. Karam and J. A. Nicell, "Potential applications of enzymes in waste treatment," Journal of Chemical Technology and Biotechnology, vol. 69, pp. 141-153, 1997.

[9] K. Ikehata and J. A. Nicell, "Characterization of tyrosinase for the treatment of aqueous phenols," Bioresource Technology, vol. 74, no. 3, pp. 191-199, 2000.

[10] N. Durán and E. Esposito, "Potential applications of oxidative enzymes and phenoloxidase-like compounds in wastewater and soil treatment: a review," Applied Catalysis B, vol. 28, no. 2, pp. 83-99, 2000.

[11] D. López-Molina, A. N. P. Hiner, J. Tudela, F. García-Cánovas, and J. N. Rodríguez-López, "Enzymatic removal of phenols from aqueous solution by artichoke (Cynara scolymus L.) extracts," Enzyme and Microbial Technology, vol. 33, no. 5, pp. 738-742, 2003.

[12] A. Guerra, A. Ferraz, A. R. Cotrim, and F. T. Da Silva, "Polymerization of lignin fragments contained in a model effluent by polyphenoloxidases and horseradish peroxidase/hydrogen peroxide system," Enzyme and Microbial Technology, vol. 26, no. 5-6, pp. 315-323, 2000.

[13] Y. J. Xuan, Y. Endo, and K. Fujimoto, "Oxidative degradation of bisphenol A by crude enzyme prepared from potato," Journal of 
Agricultural and Food Chemistry, vol. 50, no. 22, pp. 6575-6578, 2002.

[14] A. A. Khan and Q. Husain, "Decolorization and removal of textile and non-textile dyes from polluted wastewater and dyeing effluent by using potato (Solanum tuberosum) soluble and immobilized polyphenol oxidase," Bioresource Technology, vol. 98, no. 5, pp. 1012-1019, 2007.

[15] N. Lončar, N. Božić, I. Andelković et al., "Removal of aqueous phenol and phenol derivatives by immobilized potato polyphenol oxidase," Journal of the Serbian Chemical Society, vol. 76, no. 4, pp. 513-522, 2011.

[16] M.-F. Hou, X.-Y. Tang, W.-D. Zhang, L. Liao, and H.-F. Wan, "Degradation of pentachlorophenol by potato polyphenol oxidase," Journal of Agricultural and Food Chemistry, vol. 59, no. 21, pp. 11456-11460, 2011.

[17] J. Shao, L.-L. Huang, and Y.-M. Yang, "Immobilization of polyphenol oxidase on alginate- $\mathrm{SiO}_{2}$ hybrid gel: stability and preliminary applications in the removal of aqueous phenol," Journal of Chemical Technology and Biotechnology, vol. 84, no. 4, pp. 633-635, 2009.

[18] N. Lončar, B. Janović, M. Vujčić, and Z. Vujčić, “Decolorization of textile dyes and effluents using potato (Solanum tuberosum) phenoloxidase," International Biodeterioration and Biodegradation, vol. 72, pp. 42-45, 2012.

[19] H. Saruta, Y. Ashihara, and M. Sugiyama, "Colorimetric determination of carboxypeptidase A activity in serum," Clinical Chemistry, vol. 32, no. 5, pp. 748-751, 1986.

[20] M. M. Bradford, "A rapid and sensitive method for the quantitation of microgram quantities of protein utilizing the principle of protein dye binding," Analytical Biochemistry, vol. 72, no. 1-2, pp. 248-254, 1976.

[21] Y. Wu, K. E. Taylor, N. Biswas, and J. K. Bewtra, "Comparison of additives in the removal of phenolic compounds by peroxidasecatalyzed polymerization," Water Research, vol. 31, no. 11, pp. 2699-2704, 1997.

[22] J. A. Nicell, K. W. Saadi, and I. D. Buchanan, "Phenol polymerization and precipitation by horseradish peroxidase enzyme and an additive," Bioresource Technology, vol. 54, no. 1, pp. 5-16, 1995.

[23] D. A. Abukharma and H. U. Woolhouse, "The preparation and properties of $o$-diphenol: oxygen oxidoreductase from potato tubers," New Phytologist, vol. 65, pp. 477-478, 1966.

[24] S. S. Patil and M. Zucker, "Potato phenolases. Purification and properties," Journal of Biological Chemistry, vol. 240, no. 10, pp. 3938-3943, 1965.

[25] A. Sánchez-Ferrer, F. Laveda, and F. García-Carmona, "Partial purification of soluble potato polyphenol oxidase by partitioning in an aqueous two-phase system," Journal of Agricultural and Food Chemistry, vol. 41, no. 8, pp. 1219-1224, 1993.

[26] J. Batistuti and E. J. Lourenço, "Isolation and purification of polyphenol oxidase from a new variety of potato," Food Chemistry, vol. 18, no. 4, pp. 251-263, 1985.

[27] P. W. Thygesen, I. B. Dry, and S. P. Robinson, "Polyphenol oxidase in potato. A multigene family that exhibits differential expression patterns," Plant Physiology, vol. 109, no. 2, pp. 525531, 1995.

[28] Q. Huang, J. Tang, and W. J. Weber Jr., "Precipitation of enzymecatalyzed phenol oxidative coupling products: background ion and pH effects," Water Research, vol. 39, no. 13, pp. 3021-3027, 2005.

[29] K. Yamada, T. Shibuya, M. Noda et al., "Influence of position of substituent groups on removal of chlorophenols and cresols by horseradish peroxidase and determination of optimum conditions," Bioscience, Biotechnology and Biochemistry, vol. 71, no. 10, pp. 2503-2510, 2007.

[30] A. D’Annibale, S. R. Stazi, V. Vinciguerra, and G. Giovannozzi Sermanni, "Oxirane-immobilized Lentinula edodes laccase: stability and phenolics removal efficiency in olive mill wastewater," Journal of Biotechnology, vol. 77, no. 2-3, pp. 265-273, 2000.

[31] H. Azaizeh, F. Halahlih, N. Najami, D. Brunner, M. Faulstich, and A. Tafesh, "Antioxidant activity of phenolic fractions in olive mill wastewater," Food Chemistry, vol. 134, no. 4, pp. 22262234, 2012.

[32] A. El-Abbassi, H. Kiai, and A. Hafidi, "Phenolic profile and antioxidant activities of olive mill wastewater," Food Chemistry, vol. 132, no. 1, pp. 406-412, 2012.

[33] A. A. DeebA, M. K. Fayyad, and M. A. Alawi, "Separation of polyphenols from Jordanian olive oil mill wastewater," Chromatography Research International, vol. 1, pp. 1-8, 2012.

[34] A. Scoma, C. Pintucci, L. Bertin, P. Carlozzi, and F. Fava, "Increasing the large scale feasibility of a solid phase extraction procedure for the recovery of natural antioxidants from olive mill wastewaters," Chemical Engineering Journal, vol. 198-199, pp. 103-109, 2012.

[35] A. Cardinali, S. Pati, F. Minervini, I. D’Antuono, V. Linsalata, and V. Lattanzio, "Verbascoside, isoverbascoside, and their derivatives recovered from olive mill wastewater as possible food antioxidants," Journal of Agricultural and Food Chemistry, vol. 60, no. 7, pp. 1822-1829, 2012.

[36] H. K. Obied, M. S. Allen, D. R. Bedgood, P. D. Prenzler, K. Robards, and R. Stockmann, "Bioactivity and analysis of biophenols recovered from olive mill waste," Journal of Agricultural and Food Chemistry, vol. 53, no. 4, pp. 823-837, 2005.

[37] T. Jerman Klen and B. Mozetič Vodopivec, "Ultrasonic extraction of phenols from olive mill wastewater: comparison with conventional methods," Journal of Agricultural and Food Chemistry, vol. 59, no. 24, pp. 12725-12731, 2011.

[38] R. Yoruk and M. R. Marshall, "Physicochemical properties and function of plant polyphenol oxidase: a review," Journal of Food Biochemistry, vol. 27, no. 5, pp. 361-422, 2003.

[39] G. Toscano, M. L. Colarieti, and G. Greco Jr., "Oxidative polymerisation of phenols by a phenol oxidase from green olives," Enzyme and Microbial Technology, vol. 33, no. 1, pp. 4754, 2003.

[40] D. Ni Eidhin, P. Degn, and D. O’beirne, "Characterization of polyphenol oxidase from rooster potato (Solanum tuberosum $\mathrm{cv}$ Rooster)," Journal of Food Biochemistry, vol. 34, no. 1, pp. 13-30, 2010.

[41] S. P. Kowalski, N. T. Eannetta, A. T. Hirzel, and J. C. Steffens, "Purification and characterization of polyphenol oxidase from glandular trichomes of Solanum berthaultii," Plant Physiology, vol. 100, no. 2, pp. 677-684, 1992.

[42] P. Sarni-Manchado, V. Cheynier, and M. Moutounet, "Reactions of polyphenoloxidase generated caftaric acid $o$-quinone with malvidin 3-O-glucoside," Phytochemistry, vol. 45, no. 7, pp. 1365-1369, 1997.

[43] K. Robards, P. D. Prenzler, G. Tucker, P. Swatsitang, and W. Glover, "Phenolic compounds and their role in oxidative processes in fruits," Food Chemistry, vol. 66, no. 4, pp. 401-436, 1999.

[44] S. Kobayashi and H. Higashimura, "Oxidative polymerization of phenols revisited," Progress in Polymer Science (Oxford), vol. 28, no. 6, pp. 1015-1048, 2003. 
[45] S. Mukherjee, B. Basak, B. Bhunia, A. Dey, and B. Mondal, "Potential use of polyphenol oxidases (PPO) in the bioremediation of phenolic contaminants containing industrial wastewater," Reviews in Environmental Science and Biotechnology, vol. 12, pp. 61-73, 2013.

[46] M. De Lucia, L. Panzella, A. Pezzella, A. Napolitano, and M. D'Ischia, "Oxidative chemistry of the natural antioxidant hydroxytyrosol: hydrogen peroxide-dependent hydroxylation and hydroxyquinone/o-quinone coupling pathways," Tetrahedron, vol. 62, no. 6, pp. 1273-1278, 2006. 

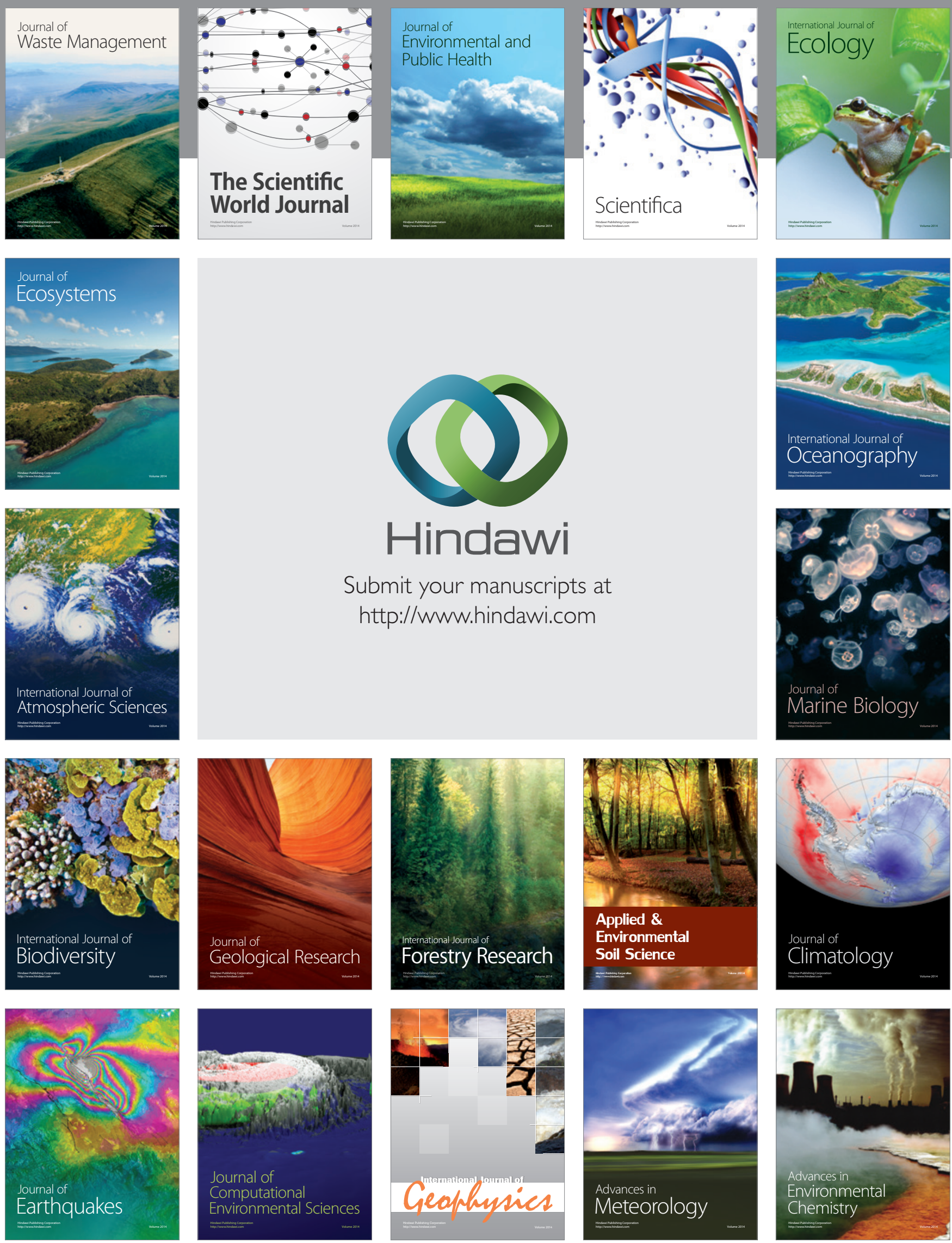